
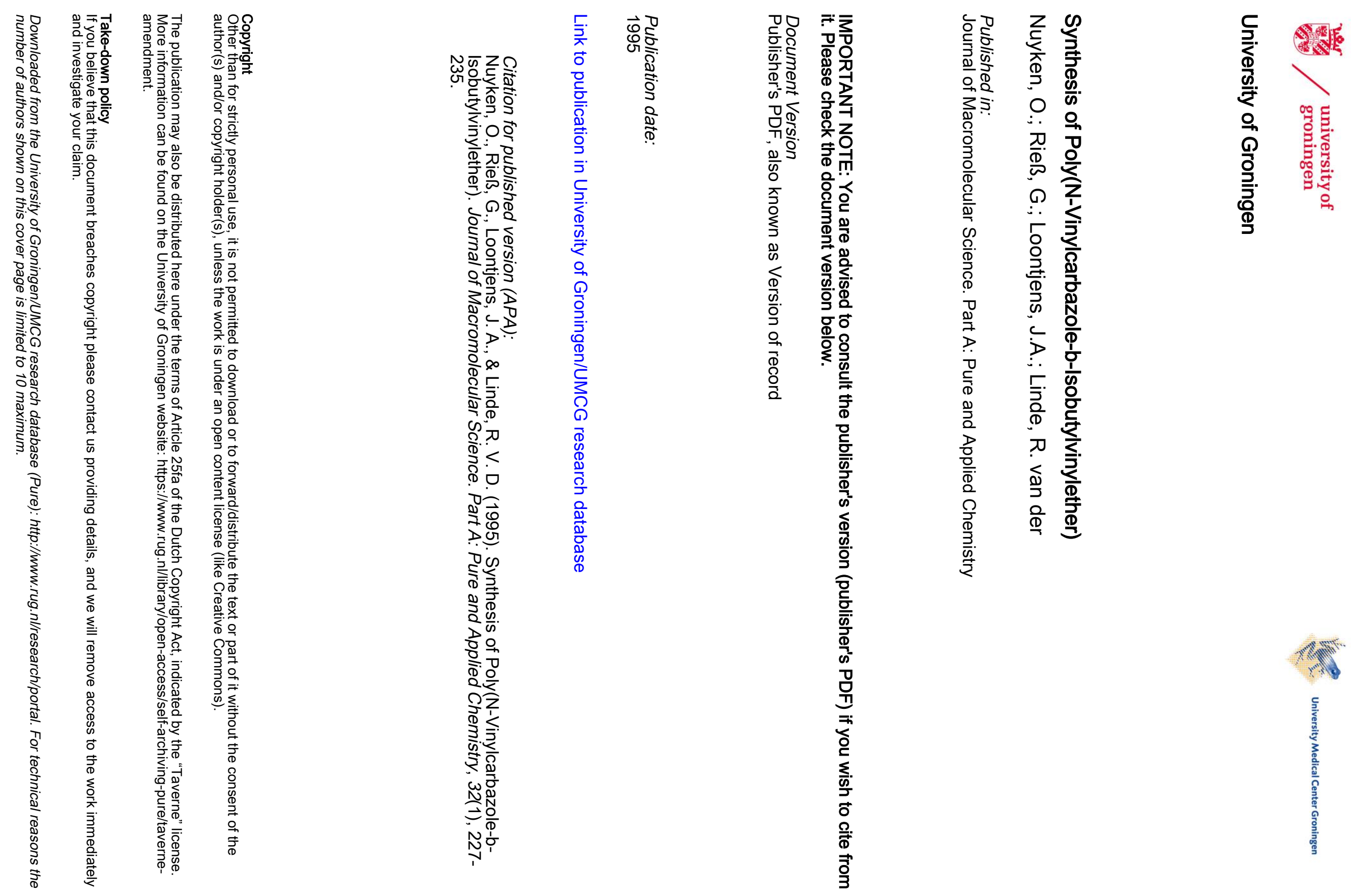


\title{
SYNTHESIS OF POLY(N-VINYLCARBAZOLE-b-ISOBUTYLVINYLETHER)
}

\author{
O. Nuyken*, G. Ries \\ Lehrstuhl für Makromolekulare stoffe \\ Technische Universität München \\ Lichtenbergstraße 4, D-85747 Garching, Germany \\ J.A. Loontjens \\ DSM, Research, PO box 18 \\ NL-6160 MD Geleen, The Netherlands \\ R. van der Linde \\ DSM Resin b.v., P.O.Box 615 \\ NL-8000 AP Zwolle, The Netherlands
}

\begin{abstract}
Blockcopolymers consisting of $\mathrm{N}$-vinylcarbazole (NVC) and isobutylvinylether (IBVE) were synthesized by sequential monomer addition. It is essential to start the synthesis with the NVC-segment and to initiate the polymerization by 1-iodo-1-(2-methylpropyloxy) ethane. The blockcopolymerization of IBVE proceeds only in the presence of an activator, such as $(\mathrm{n}-\mathrm{Bu})_{4} \mathrm{NClO}_{4}$. The blockcopolymers were characterized by GPC, ${ }^{1} \mathrm{H}$ NMR, elemental analysis and DSC.
\end{abstract}

\section{INTRODUCTION}

From earlier studies we know that 1-iodo-1-12methylpropyloxy)ethane is a suitable initiator for the polymerization of $\mathrm{NVC}^{1)}$. We were able to show that poly ( $\mathrm{N}-$ vinylcarbazole) (poly (NVC)) can be obtained with a molar mass which is controlled by [M] : [I], and that molar mass distribution is narrow. Furthermore, incremental monomer 
addition experiments indicated that all chain ends could be reactivated again for a further polymerization.

These observations encouraged us to look for conditions which allow blockcopolymerization.

It was also known that the polymerization of isobutylvinylether by 1-iodo-1-(2-methylpropyloxy) ethane 1 alone failed. The addition of an activator $\left((\mathrm{n}-\mathrm{Bu})_{4} \mathrm{NClO}_{4}\right)$ is needed ${ }^{2)}$. The polymerization of NVC in the presence of both 1-iodo-1-(2-methylpropyloxy) ethane and $(\mathrm{n}-\mathrm{Bu})_{4} \mathrm{NClO}_{4}$ is not living. Consequently, it was essential to start the synthesis of the blockcopolymer with the NVC-segment initiated by 1 alone.

\section{RESULTS AND DISCUSSION}

Poly (N-vinylcarbazole-b-isobutylvinylether) (poly (NVC-bIBVE)) was synthesized according to the following scheme:<smiles>CC(C)COC(C)I</smiles>

1<smiles>C=Cn1c2ccccc2c2ccccc21</smiles>

$\mathbf{M}_{1}$<smiles>CC(C)COC(C)C(C)CCC(n1c2ccccc2c2ccccc21)C(C)(C)I</smiles>

P1

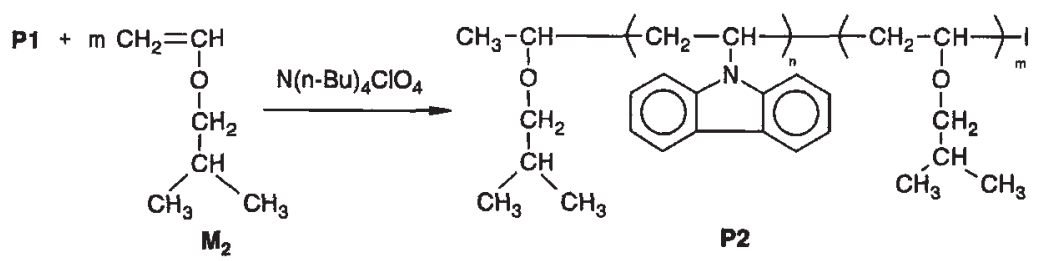

P2 $\stackrel{\mathrm{CH}_{3} \mathrm{OH}}{\longrightarrow}$<smiles>COC(C)COCC(C)CCn1c2ccccc2c2ccccc21</smiles> 
Polymerization of NVC was initiated with 1-iodo-1-(2methylpropyloxy)ethane (1) at $-50^{\circ} \mathrm{C}$ - conversion was followed by GC with xylene as internal standard.

After complete conversion of $M_{1}$ the temperature was raised to $-20^{\circ} \mathrm{C}$ and then the IBVE $\left(\mathrm{M}_{2}\right)$ was added. However, no polymerization was observed before the activator $(\mathrm{n}-\mathrm{Bu})_{4} \mathrm{NClO}_{4}$ was added, meaning that $\mathrm{Pl}$ alone was not able to start a IBVE polymerization.

As one can see from TABLE 1, both monomers were converted almost completely. Furthermore, in all cases monomodal GPC curves were received, which we consider a strong indication that blockcopolymers of NVC and IBVE are formed.

The calculated and the observed molar masses are similar, indicating that both monomers react in a living manner. We have been surprised to see that calibration of the GPC with polystyrene works perfect for poly (NVCb-IBVE). This is supported by independent tests by vapor pressure osmometry (exp. 1, exp. 6) (TABLE 2).

The composition of blockcopolymers was determined by proton NMR and elemental analysis. A typical ${ }^{1} \mathrm{H}$ NMRspectrum of a poly (NVC-b-IBVE) is shown in FIG. 1 .

Since the spectrum contains independent signals belonging to each of the units: area between 8 and 4,5 ppm corresponds with 8 protons of NVC (a) signal at 0,9 ppm corresponds with 6 protons of IBVE (h), it is possible to calculate the composition of the blockcopolymer on the basis of the following simple relation:

$$
\begin{gathered}
X_{\mathrm{NVC}}=\frac{I_{\mathrm{NVC}}}{I_{\mathrm{NVC}}+I_{\mathrm{IBVE}}} \\
I_{\mathrm{NVC}}=\mathrm{a} / 8 ; \mathrm{a}=\text { area between } 8 \text { and } 4,5 \mathrm{ppm} \\
I_{\mathrm{IBVE}}=\mathrm{h} / 6 ; \mathrm{h}=\text { area of signal at } 0,9 \mathrm{ppm}
\end{gathered}
$$


TABLE 1:

Blockcopolymers for NVC and IBVE

Initiator: 1-iodo-1-(2-methylpropyloxy)ethane (1)

for $\mathrm{NVC}$, and $1 /(\mathrm{n}-\mathrm{Bu})_{4} \mathrm{NClO}_{4}$ (2) for IBVE

$\mathrm{T}=-50^{\circ} \mathrm{C}$ for $\mathrm{NVC}, \mathrm{T}=-20^{\circ} \mathrm{C}$ for IBVE

\begin{tabular}{|c|c|c|c|c|c|c|c|}
\hline $\operatorname{Exp}$ & $\begin{array}{l}{[\mathrm{NVC}]} \\
\operatorname{mol} 1^{-1}\end{array}$ & $\begin{array}{l}\text { [1] } \\
\operatorname{mol} 1^{-1}\end{array}$ & $\begin{array}{l}C^{\text {a) }} \\
\frac{8}{6}\end{array}$ & $\begin{array}{l}\text { [IBVE] } \\
\operatorname{mol} 1^{-1}\end{array}$ & $\begin{array}{l}\text { [1] } \\
\operatorname{mol} 1^{-1}\end{array}$ & $\begin{array}{l}{[2]} \\
\operatorname{mol} 1^{-1}\end{array}$ & $\begin{array}{l}C^{b)} \\
\frac{8}{8}\end{array}$ \\
\hline 1 & 0,15 & 0,01 & 98,6 & 0,13 & 0,009 & 0,0095 & 90,6 \\
\hline 2 & 0,17 & 0,01 & 95,3 & 0,13 & 0,009 & 0,0083 & 85,2 \\
\hline 3 & 0,20 & 0,01 & 96,7 & 0,13 & 0,009 & 0,0091 & 91,7 \\
\hline 4 & 0,15 & 0,01 & 96,3 & 0,28 & 0,009 & 0,0090 & 91,7 \\
\hline 5 & 0,15 & 0,01 & 97,8 & 0,23 & 0,009 & 0,0090 & 94,3 \\
\hline 6 & 0,14 & 0,0035 & $65,5^{c)}$ & 0,13 & 0,003 & 0,0030 & 37,4 \\
\hline
\end{tabular}

a) Conversion of NVC after 3 hrs;

b) Conversion of IBVE after 1,5 hrs

c) A conversion of $93.6 \%$ was reached after raising the temperature to $-20^{\circ} \mathrm{C}$.

$\mathrm{x}_{\mathrm{NVC}}=\mathrm{n} /[\mathrm{n}+(\mathrm{m}+1)] ; \mathrm{n}=$ number of repeating units of NVC, $m=$ number of repeating units of IBVE $(+1$, due to the initiator unit).

The composition of the blockcopolymer is also calculated on the basis of the elemental analysis. The results of proton NMR and elemental analysis are compared with calculated values based on the conversion data in TABLE 3.

THERMAL PROPERTIES OF POLY (NVC-b-IBVE)

It is known that the glass transition temperature of both homopolymer PNVC and PIBVE are very different: Tg 
TABLE 2:

Molar masses of the poly (NVC-b-IBVE)

\begin{tabular}{ccccc} 
Exp. & $M_{n}($ GPC $)$ & $M_{n}($ VPO $)$ & $M_{n}(\text { calc })^{a}$ & $M_{w} / M_{n}$ \\
\hline 1 & 4390 & 3900 & 4340 & 1,34 \\
2 & 5200 & - & 4650 & 1,40 \\
3 & 5420 & - & 5320 & 1,46 \\
4 & 5620 & - & 5890 & 1,45 \\
5 & 5880 & - & 5440 & 1,45 \\
6 & 8810 & 8200 & 9350 & 1,50 \\
\hline
\end{tabular}

a) calc. from $M_{n}=\left[M_{1}\right] /\left[I_{1}\right] \cdot C_{1} * \cdot M_{M 1}$

$$
+\left[M_{2}\right] /\left[I_{2}\right] \cdot C_{2} * \cdot M_{M 2}+M_{\text {head }}+M_{\text {end }}
$$

* $\mathrm{C}=$ conversion
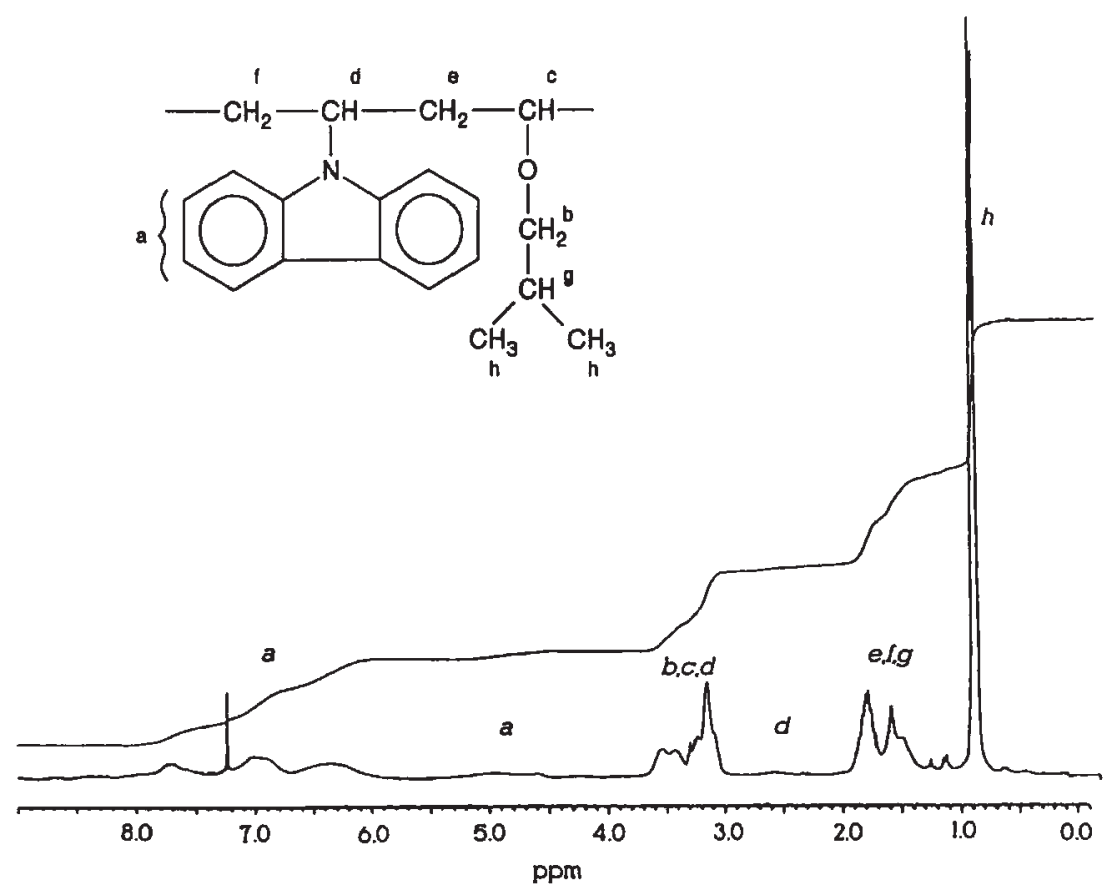

Fig. 1: ${ }^{1} \mathrm{H}$ NMR of poly (NVP-Co-IBVE) in $\mathrm{CDCl}_{3}$. 
TABLE 3:

Composition of the blockcopolymers in mol\%

\begin{tabular}{|c|c|c|c|c|c|c|}
\hline \multirow[t]{2}{*}{$\operatorname{Exp}$} & \multicolumn{3}{|c|}{ NVC } & \multicolumn{3}{|c|}{ IBVE } \\
\hline & calc. a) & ${ }^{1} \mathrm{H} \quad \mathrm{NMR}$ & $E A^{c)}$ & calc.b) & ${ }^{1} \mathrm{H} \quad \mathrm{NMR}$ & $E A^{c)}$ \\
\hline$\overline{1}$ & 51,5 & 54,9 & 54,4 & 48,5 & 45,1 & 45,6 \\
\hline 2 & 56,1 & 58,5 & 59,5 & 43,9 & 41,5 & 40,5 \\
\hline 3 & 58,5 & 68,4 & 67,7 & 41,5 & 31,6 & 32,3 \\
\hline 4 & 33,7 & 32,1 & 27,5 & 66,3 & 67,9 & 72,5 \\
\hline 5 & 37,4 & 40,0 & 36,7 & 62,6 & 60,0 & 63,3 \\
\hline 6 & 69,9 & 74,4 & 73,1 & 30,1 & 25,6 & 26,9 \\
\hline
\end{tabular}

a) based on complete conversion of NVC

b) based on the conversion, given in table 1. The number of repeating units is given by:

$\mathrm{n}=[\mathrm{IBVE}] /[\mathrm{I}] \cdot \mathrm{C}+1$ (because of the initiator unit)

c) based on the elemental analysis

$(\mathrm{PNVC}): 205^{\circ} \mathrm{C}^{3,4}, \mathrm{Tg}(\mathrm{PIBVE})=-20^{\circ} \mathrm{C}^{4}$. It was of interest whether poly (NVC-b-IBVE) would show a Tg depending on its composition or two separated Tg's. The result is shown in FIG. 2 :

Since DSC curves of the mixture of the two homopolymers and of the block copolymers are almost identical, one can conclude that the segments of the blockcopolymer have a strong tendency for phase separation.

Both Tg-values are very close to those of the homopolymers.

\section{EXPERIMENTAL PART}

\section{INSTRUMENTS}

IR: Digilab FTS-40 (FT-IR); ${ }^{1} \mathrm{H}$ NMR: Bruker AC 250 (250 $\mathrm{MHz}) ;{ }^{13} \mathrm{C}$ NMR: Bruker AC $250(62,5 \mathrm{MHz})$; GPC: Waters 510, 


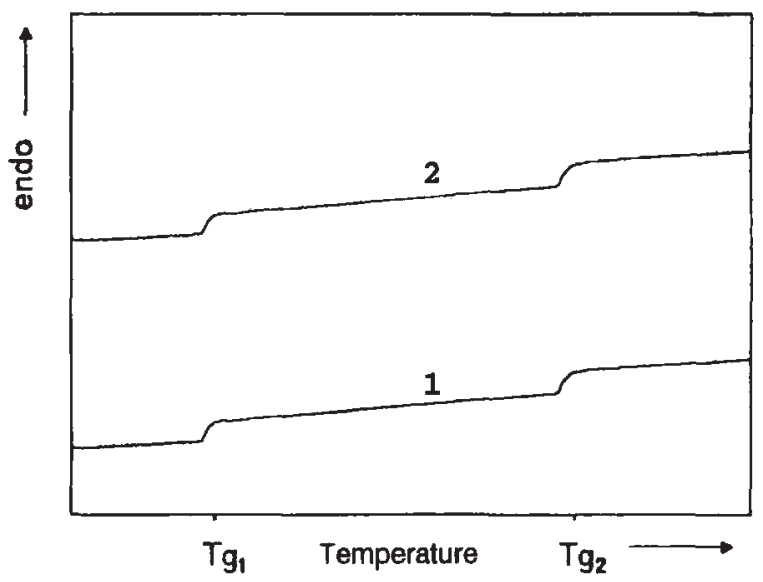

FIG. 2: DSC of poly (NVC-b-IBVE) (2) and a mixture of PNVC and PIBVE (1)

RI 590, eluent: THF; DSC: Perkin Elmer DSC7; GC: Varian GC 3700, column. CP Sil 5CB; Elemental analysis: Ilse Beetz, Kronach; Cryostate: Lauda UK 8 DW.

\section{CHEMICALS}

$\mathrm{CH}_{2} \mathrm{Cl}_{2}$ was dried over $\mathrm{CaH}_{2}$. Xylene was dried with sodium. $\mathrm{N}$-vinylcarbazole (Fluka) was recrystallized from nhexane. Isobutylvinylether (Fluka) was refluxed over $\mathrm{CaH}_{2}$ and it was freshly destilled before use.

$(\mathrm{n}-\mathrm{Bu})_{4} \mathrm{NClO}_{4}$ (Fluka) was dried for $24 \mathrm{hrs}$. under high vacuum conditions and then it was stored under argon. 1iodo-1 (2-methylpropyloxy) ethane (1) was synthesized as described in the literature ${ }^{21}$.

\section{Polymerization}

The polymerization was started with NVC/I /values see TABLE 1) in $\mathrm{CH}_{2} \mathrm{Cl}_{2}$ at $-50^{\circ} \mathrm{C}$ in the presence of xylene as internal standard (for quant. determination of conversion by GC). After complete conversion of NVC a 
certain amount of IBVE (see TABLE 1) was added. The system was heated to $-20^{\circ} \mathrm{C}$ before the polymerization was started by addition of the activator $(\mathrm{n}-\mathrm{Bu})_{4} \mathrm{NClO}_{4}$. The progress of polymerization was followed by GC.

After $\sim 90 \%$ conversion of IBVE the polymerization was quenched with methanol/aqu. $\mathrm{NH}_{3}$, the precipitated polymer was collected by filtration, dried and characterized.

Characterization

${ }^{1} \mathrm{H}$ NMR $\left(\mathrm{CDCl}_{3}\right) \delta(\mathrm{ppm}): 5,8-8,0\left(\mathrm{H}^{\mathrm{a}}\right), 4,5-5,2\left(\mathrm{H}^{\mathrm{a}}\right), 3,0-$ $3,9\left(\mathrm{H}^{b}, \mathrm{H}^{\mathrm{c}}, \mathrm{H}^{\mathrm{d}}\right), 2,3-2,8\left(\mathrm{H}^{\mathrm{d}}\right), 1,0-2,0\left(\mathrm{H}^{\mathrm{e}}, \mathrm{H}^{\mathrm{f}}, \mathrm{H}^{\mathrm{g}}\right), 0,9$ $\left(\mathrm{H}^{\mathrm{h}}\right)$

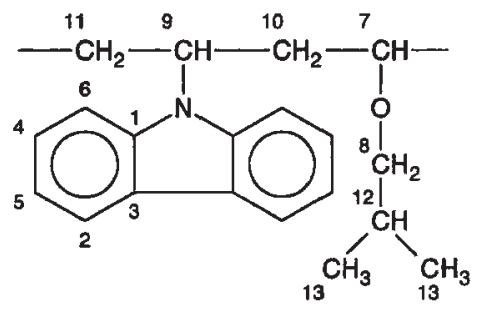

${ }^{3} \mathrm{C}$ NMR $\left(\mathrm{CDCl}_{3}\right) \delta(\mathrm{ppm}): 140,4$ and $137,9\left(\mathrm{C}^{1}\right), 125\left(\mathrm{C}^{2}\right)$, 123,8 and $122,2\left(C^{3}\right), 120,3\left(C^{4}\right), 119,6\left(C^{5}\right), 111,5$ and 108,2 $\left(C^{6}\right), 75,6\left(C^{7}\right), 73,6\left(C^{8}\right), 48,5\left(C^{9}\right), 42-37\left(C^{10}\right)$, $37-33\left(C^{11}\right), 28,8\left(C^{12}\right), 19,6\left(C^{13}\right)$

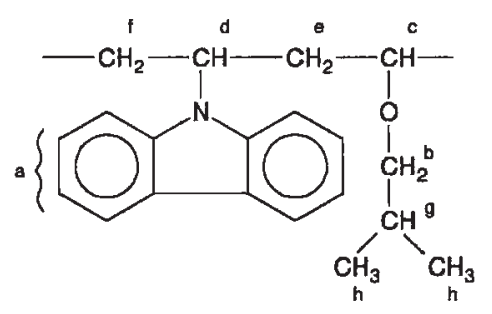

ACKNOWLEDGEMENT

The authors wish to thank the DSM company Geleen for Einancial support and Dr. Derks for helpful discussions. 


\section{REFERENCES}

1. O. Nuyken, G. Rieß, J.A. Loontjens, Macromol. Reports, submitted

2. O. Nuyken, H. Kröner, Makromol. Chem. 191, 1 (1990)

3. D. R. Terrel, F. Evers, J. Polym. Sci. 20, 2529 (1982)

4. G. Rieß, Dr.-Thesis, Bayreuth 1993, p. 34; 52 